\title{
İmit Channel and Its History in the Light of Paleontological Findings
}

\author{
Engin Meric \\ AMBRD Laboratories, Istanbul, Turkey \\ Email address: \\ bakiyokes@gmail.com \\ To cite this article: \\ Engin Meric. İzmit Channel and Its History in the Light of Paleontological Findings. American Journal of Environmental Science and \\ Engineering. Vol. 5, No. 1, 2021, pp. 1-5. doi: 10.11648/j.ajese.20210501.11
}

Received: March 1, 2019; Accepted: April 11, 2019; Published: January 4, 2021

\begin{abstract}
During the Ottoman Empire, a waterway without a Black Sea connection has been suggested through Sakarya River, Sapanca Lake and Gulf of İzmit and has been attempted six times. A natural connection between the Black Sea and the Sea of Marmara through that route has been proven according to findings of the drills taken for "the Osman Gazi Bridge" in 1990. Samples belonging to nine deep drills made for the bridge have been investigated in the four years and the results were compiled in the book "Quaternary sequence in the Gulf of İzmit. New data obtained from the recent drills made in the frame work of the bridge Project have strongly supported the previous results. In 1997, considering the paleontological findings of the Gulf of İzmit drills, which were completed in 1995, it has been indicated that İzmit Channel naturally opened and closed five times during Quaternary, between 800.000 and 80.000 years bp. 1-Regarding this information, the subject has been presented for the first time with the abstract titled "Back to the past for the future" (in Turkish), In Sea of Marmara Researchers Workshop-III, which was held in Ankara 1997. 2-It was presented to the International scientific community during The Geological Society of America, Annual Meeting, which was held in Salt Lake City, Utah (USA) in 20-23 October 1997, with the abstract titled "Back to the past for the future". 3-In February 1998, it was proposed as KAP (Kuzeybatı Anadolu Projesi, Northwestern Anatolia Project) to the 9th President of the Republic Mr. Süleyman Demirel. 4-The subject was also proposed to Undersecretariat of Maritime Affairs, Undersecretariat of DPT (State Planning Organization), Undersecretariat of Ministry of Transportation İzmit Metropolitan Municipality and Sakarya Municipality. 5-More than 10 articles were published in various journals. 6-Before the general elections in 2002, "New İzmit Channel Project" was taken to the "Government Program" prepared by the Doğru Yol Party. 7-It was accepted by DPT and in 22.01 .2005 it was proposed as one of the "10 projects for Turkey's future" in "5. Solutions of Turkey's Problems Conference". 8-Besides, a "Registration Certificate" related to "New İzmit Channel Project" was acquired from TR Ministry of Culture and Tourism, General Directorate of Copyrights and Cinema (date: 17 June 2009, article no: B. 16.0. THS. 10.03.00/15995). 9-Detailed information given by Ord. Prof. İsmail Hakk1 Uzunçarşıll, were quoted from his work published in "Belleten Dergisi” Volume 4, issue 14-15, April-July 1940.
\end{abstract}

Keywords: Sakarya River, Sapanca Lake, Gulf of İzmit, İzmit Channel

\section{Introduction}

According to the paleontological data obtained from the investigation of the drillings made in 1990 for the Osman Gazi Bridge, a natural connection between the Black Sea and the Sea of Marmara has been found on the Lower Sakarya Valley, Sapanca Lake and Gulf of İzmit. This natural connection ceased to be 80,000 years ago. Russian geoscientists have argued that this connection took place naturally three times in the period between 800,000 and 80,000 years ago. Considering the paleontological findings obtained from the Gulf of İzmit drillings completed in 1995, Sakarya Valley, Sapanca Lake and Gulf of İzmit the connection naturally opened 3 times between 800,000 to 80,000 years ago in the Quaternary period. The İzmit Channel is mentioned for the first time in 1997 and it has been shown that the natural connection can be artificially constructed in accordance with today's conditions.

In 2010, the samples of the 4 drillings in the northern area and 3 in the southern area were re-examined in order to obtain detailed information for the bridge construction. In order to support this idea, detailed studies on the foraminifera, 
ostracod and mollusks have been made and the results of the Black Sea-Marmara Sea connection can be determined.

The first studies for the Osman Gazi Bridge started 27 years ago. The multidisciplinary research was carried out for more than 4 years by 42 scientists, five of whom were foreigners (Israel, Italy, France, England and Russia), on the samples of 9 deep drilling made for the bridge. The results were published as a book consisting of 27 sections and 355 pages with the name of Gulf of İzmit Quaternary Sequence, and at the end of 1995 it was presented to the scientific world. Various studies in the book have received more than 450 citations. Although these drillings were made for Osman Gazi Bridge, unexpected results were obtained with regard to the history of the region. The new data from recent drillings under the aforementioned bridge project strongly support the same results. This idea, first proposed by Russian scientist Andrussow [1], is also supported by the data obtained today [2-6]. Tschepalyga also reported that the waterway was naturally open in the Chaudian (between 800,000-500,000 years bp), the Old Euxinian (between 450,000-350,000 years bp) and the Karangatian (150,000-80,000 years bp) [7]; also suggested that it was closed naturally in the Uzunlarien (300,000-200,000 years bp) and in the New Euxinian (27,000-11,800 years bp). In another study carried out around Yalova, it was determined that there were terraces indicating the presence of the Karangatian macrofauna [8]. This data clearly reveals the presence of the natural waterway between Sakarya Valley-Sapanca Lake and Gulf of İzmit. In addition to that, it was the Russian scientists that named it "The İzmit Channel" [7]. In the same period there was also another natural waterway called the "Manych Channel", again named by the Russians, between the Sea of Azov and the Caspian Sea. Today, this channel, where small tonnage ships cross, was also open like the İzmit Channel during the Chaudian, Old Euxinian and Karangatian periods (Figure 1) [7]. According to the historian Hammer, the creation of a waterway between the Black Sea and the Sea of Marmara was mentioned by the Roman Emperor Trajan (Traianus) for the first time. He is the second of five successful emperors of the Roman Empire. He lived between 53-117 AD. In order to establish a connection between Sapanca Lake and the Gulf of İzmit within the boundaries of Nicomedia (İzmit), the Emperor was informed by Plinius, who was the governor of Bithynia and who knew the region well [9]. In addition, the Sakarya River has been proposed to be connected to the lake.

Let us turn to the past and remind ourselves of the channel projects in the Ottoman Empire period, reviewed by Uzunçarşılı (1940) and Ağıralioğlu (2016) [10-11]. The idea was that the creation of a waterway connection between the first channel project outside of today's Republic of Turkey in 1570 by Sokullu Mehmet Pasha, the Don and Volga rivers, combined with an artificial channel of the Black Sea, Azov Sea and Caspian Sea. The Ottoman navy would then be able to reach the Caspian Sea and establish relations between the
Central Asian Turkish States and the Ottoman Empire in different areas. After the first Siege of Vienna 450 years ago, Sokullu Mehmet Pasha wanted to realize this channel project by thinking that it would be more accurate that the Ottomans would reach Central Asian Turkish States rather than Europe. Another important issue related to this was the reimplementation of the natural Manych Channel ley, which had existed during the Pleistocene period, as mentioned earlier. It can be seen that Sokullu Mehmet Pasha, as a forward-thinking statesman, had already considered that the Ottoman Empire should seek its future in Central Asia, not in Europe. Perhaps its purpose was to establish a great TurkishIslamic State in the region from Eastern Europe to Central Asia, from the Caucasus to the Indian Ocean and North Africa. If the artificial construction of the Manych Channel, which was naturally present in the Quaternary, had been realized, the flow of history would be different from the present, but Sokullu Mehmet Pasha failed to realize this idea throughout his life. The second channel event is the Suez Canal, which is one of the key points of the First World War, which today is an important water and politically important waterway. The Suez settlement was a small city in Egypt, which had been part of the Ottoman Empire for a long time. The Suez Canal was built between 1859 and 1869 under the administration of the Frenchman Ferdinand de Lesseps. The channel, which is composed of young Pleistocene sediments such as Gulf of İzmit-Sapanca Lake and built on flat land, was realized by utilizing natural water areas such as Büyük Acı Lake, Küçük Acı Lake and Crocodile Lake. The channel, which shortened the London-Bombay sea route by $44 \%$, created a major political problem in the UK and France over time. The British Empire, which now holds the southern Asian states known as India and Pakistan as colonies, had worked hard to destroy the French influence in this region. As a result, with the Treaty of Istanbul dated October 29, 1888 , it was ensured that the channel was open to ships of all countries in both war and peace. Again, in the first and second world wars, the strategic position of the channel became very important, and the channel area was the scene of the Ottoman Operation against the British in 1915 and 1916, and the German Operation in the Second World War. With the construction of the channel, cities such as Ismailia, Port Said and Port Fuad were formed in these coastal areas. As for the İzmit Channel, as mentioned by Military Prof. İsmail Hakk1 Uzunçarşıl1, during the Ottoman Empire period, a waterway project was planned over Sakarya River and Sapanca Lake without any connection to the Black Sea, and the process was started six times in different periods (1940). According to Professor Dr. Necati Ağıralioğlu, the channel issue has been raised 9 times (2016). The aim was to transport timber needed for the shipyards, grain, vegetables and fruit from Anatolia to Istanbul, which was a big consumer in the past. 


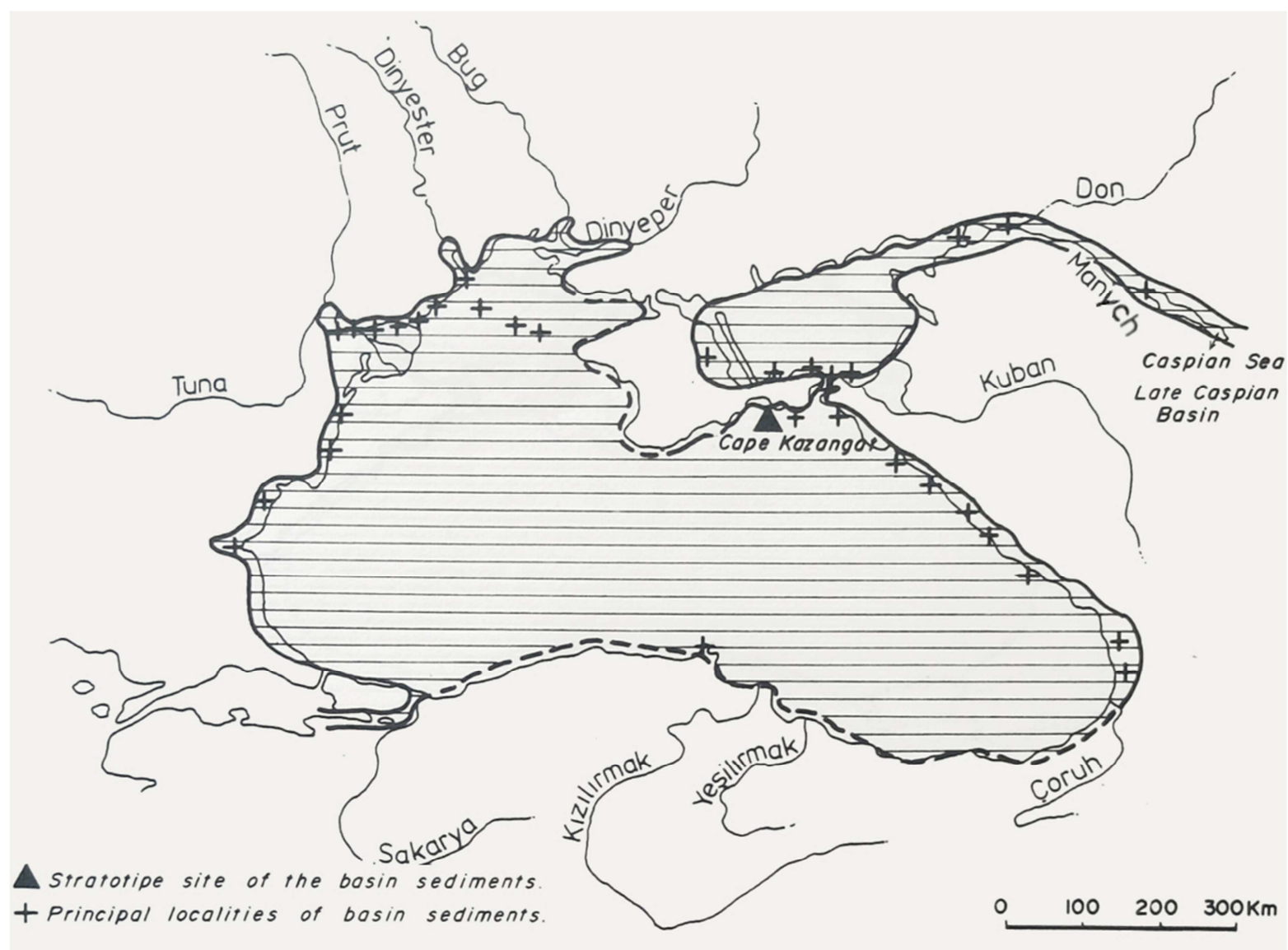

Figure 1. Sea of Marmara-Gulf of İzmit and Sea of Azov-Caspian Sea (Manych Channel) connections during Karangatian period (150,000-80,000 years bp). Today Manych Channel is still fucntional [7].

According to Hammer, the subject was first brought to the agenda during the reign of Süleyman the Magnificent, Sapanca Lake and İzmit Gulf were planned to be united. This project, in which the great architect Sinan took part, was left in the background because of some wars during that period. Considering that Süleyman the Magnificent was the ruler between 1520-1560, it is understood that the first works on the channel started in the middle of the 16th century. For the second time, during the reign of Sultan Murat III, in November 1591, the second channel project could not be realized due to economic reasons.

Developments related to this can be stated as follows: In March 1591, in order to connect Kiraz Suyu to Sapanca Lake and Sapanca Lake to the Gulf of İzmit, a series of edicts were sent to İzmit Banner Lord and İzmit and Sapanca Cadre in order to measure the distance from Gulf of İzmit, it was reported that a delegation of engineers and architects of the time were sent to the region and 30.000 workers were requested to complete the construction works quickly. Sokulluzade Hasan Pasha was appointed to supervise the excavation. Again, it was reported that such settlements would be moved to another location in case of a situation that would damage the villages, farms and dairies near the channel. This situation clearly shows that the government had given great importance to the issue of the channel. However, the issue of combining the Black Sea and the Marmara Sea, which had been emphasized so far, had fallen from the agenda due to the need for ships and naval activities. There is no historical record of the main reason for abandoning the channel construction. According to Mustafa Efendi of Thessaloniki, one of the important figures of the period, the Vizier Sinan Pasha wanted to see the channel area to be opened, and the Sultan gave him the necessary permission to do so. And Sinan Pasha assigned Mehmet Pasha in his place. At the end of a three-day examination, Sinan Pasha returned to Istanbul and explained the situation to the Sultan Murat III. However, this process could not be realized due to the intrigues of the opponents of Sinan Pasha during the period of the Ottoman Empire and as it is today.

In the following period, the construction of the channel during the reign of Sultan Mehmet IV came back to the agenda for the third time in 1654, the process was canceled for the third time with the idea that the residential areas around the channel would be greatly damaged.

During the reign of Mahmut I (1730-1754) only the Sapanca Lake was thought to be combined with the Gulf of İzmit due to the economic problems in the capital Istanbul. The aim was to bring large amounts of cereals, wood and timber in a short period of time from Sapanca and its surrounding villages. The necessary infrastructure had been prepared for the construction of the channel, but the project proposed for the 4th time was again inconclusive due to the wishes of some influential people in the region.

The subject was re-launched in the 18th century for the 
second time and the fifth time in total for Sapanca Lake water to be discharged in to the Gulf of İzmit. Sultan Mustafa III re-attempted work on the channel. In 1759, the Istanbul Government issued orders to the Governor of Kocaeli and to the regimes of İzmit, Sapanca and Adapazarı. The importance of the work is mentioned in the letter of the Sultan. As a result, excavation was started in relation to the construction of the channel, and after some excavation, ground water and the approaching winter stopped work again. In the following period attempts were again made but the personal interests of some people were dominant, and the channel issue was suspended.

In 1813 Vizier Hac1 Ahmet Aziz Pasha considered the economic importance of the channel. The ease of shipping all kinds of crops grown around the Sakarya River and Beypazarı to the Marmara Sea was reported to the authorities in Istanbul and this important issue was brought up again. Although Ahmet Aziz Pasha was appointed for the construction of the channel, the operation was stopped for the last time upon the death of the Pasha in 1814.

Then, during the reign of Sultan Abdülmecit, two attempts were made in 1845 and 1857 to establish a connection between the Black Sea and the Marmara Sea. And as always, there have been no developments due to the various obstacles that have arisen.

Finally, in 1863, the subject was brought up by Sultan Abdülaziz and the engineer Riter and Hayri Bey were assigned but no results could be reached.

This information, which was presented by Military Prof. Hakkı Uzunçarşılı and Professor Necati Ağıralioğlu, was published in Belleten Magazine [10, 11].

During the Second World War, Military Prof. Ismail Hakk1 Uzunçarş1l showed the courage to bring up the subject again during a period of great economic hardship for the Republic of Turkey. Professor Necati Ağıralioğlu, on the other hand, advocated that the İzmit Channel might be a more realistic project compared to the Istanbul Channel.

\section{Discussion}

Micro and macro organisms obtained from 40 samples of 7 drillings which were carried out in 2010 related to the construction of the Osman Gazi Bridge uncovered more detailed information. Ammonia parasovica, one of the PontoCaspian foraminifera, was found to be small in 10MB-205 and 10MB-208 drillings at different levels. Haynesina depressula and few Haynesina anglica have been identified at certain levels of 10MB-201, 10MB-203, 10 MB-204, 10MB-205, 10MB-206, 10MB-207, 10MB-208. Elphidium ponticum individuals were found in two different levels of 10MB-206 drillings. These findings are very similar to the drilling data of 1990.

10MB-201, 10MB-203, 10MB-204, 10MB-205, 10MB206, 10MB-207, 10MB-208 at certain levels of the soundings were determined as a Ponto-Caspian ostracod assemblage. These are Candona (Candona) parallela pannonica, Candona schweyeri, Candona (Pontoniella) srebarnensi,
Pseudocandona sp., Caspiolla acronasuta, Bacuniella dorsoarcuta, Amnicythere bendovanica, A. caspia, A. longa, A. olivia, A. pediformis, A. postbissinuata, $A$. quinquetuberculata, $A$. relicta, A. reticulata, A. striatacostata, Euxinocythere (Maetocythere) lopatici, E. bacuana, Tyrrenocythere amnicola, Cytherissa sp., Loxoconcha immodulata, L. lepida, Loxoconcha sp 1 sensu Boomer, 2010, Xestoleberis sp. 1.

The Ponto-Caspian mollusk assemblage was identified at different levels of 10MB-201, 10MB-203, 10MB-204, 10MB-205, 10MB-207. These are the bivalvia species Dreissena rostriformis, $D$. rostriformis pontocaspia, D. rostriformis tschaudae, Corbula gibba, Tellina donacina, Anadara sp. and gastropods Bittium latreilli, Bythinella dunkeri, Odostomia sp., Alvania sp. The community is thought to represent the Old Euxinian (450.000-350.000 years bp).

According to the preliminary results of our recent study, the Black Sea-Sea of Marmara connection had been active until 40,000-50,000 years bp, much later than Karangatian (Nazik et al., unpublished data).

As a result, through the lower Sakarya valley, Sapanca Lake and Gulf of İzmit, and between the Black Sea and the Sea of Marmara connection, more clear data is revealed. Therefore, the issue of the İzmit Channel, which was put forward for hundreds of years, but could not be finalized due to various reasons, was moved back to the agenda since 1997.

Related to this:

1 The first news about the channel appeared in Milliyet Newspaper dated 26.6.1997.

2 In 1997, in the Marmara Sea Research Workshop held in Ankara, a paper was presented with the title of Back to the past for the future. The subject was first introduced in the scientific community in the 20th century.

3 On the 16th page of Milliyet Newspaper published on July 5, 1997, Edip ÖYMEN gave an interview. The subject was announced to the society for the first time with an extensive interview titled "Let's Open a Second Bosphorus".

4 The subject was presented to the world of science at The Geological Society of America Annual Meeting, held in Salt Lake City, Utah, USA, on October 20-23, 1997 with the title "Back to the past for the future".

5 The issue was presented to the 9th President of the Republic of Turkey Süleyman Demirel as KAP (Northwest Anatolia Project) at the beginning of February 1998.

6 The subject was forwarded to the Undersecretariat for State Planning, Undersecretariat of State Planning Organization, Undersecretariat of Ministry of Transport, İzmit Metropolitan Municipality and Sakarya Municipality.

7 In the following period, more than 10 articles were published in various journals and the subject was announced to the society.

8 Before the General Elections of 2002, the İzmit 
Channel Project was included in the Government Program prepared by the Doğru Yol Party (DYP).

9 The subject was accepted by the SPO on 22.01.2005 with the participation of governors and mayors and academicians from 81 provinces and at the Turkey Issues Solutions Conference was identified as one of the 10 projects for the future of Turkey.

10 In relation to this; on 17. 06. 2009 the Ministry of Culture and Tourism General Directorate of Copyrights and Cinema as stated in the B. 16.0. THS. 0.10.03.00/15995 about the new İzmit Channel Project, Prof. Dr. Engin MERİÇ was granted a Registration Certificate.

If we evaluate the situation in general, the central residential area of Istanbul and the south of the strait, according to the northern part of the sea has heavy traffic. City line ferries, sea buses running on different lines, car ferries, fishing boats, tankers and trucks increasing the number and size each day, make this traffic increasingly unattractive.

In the first part of the 21 st century, both exports and imports will increase due to the export of oil and natural gas from Azerbaijan and Kazakhstan, and therefore the sea traffic of the Bosporus will face major problems. Considering these reasons, the İzmit water channel should be started as soon as possible. As with many issues, the build-operate model can be introduced in the channel. The issue should be evaluated considering the increase in world trade volume. In this case, specified in the fifth "Turkey Issues Solutions Conference" held in 2005 "10 projects for the future of Turkey" the time has come to implement this huge project, as it is overdue.

\section{Conclusion}

There is a big difference between the Istanbul Channel and the İzmit Channel which are frequently on the agenda today. Considering the İzmit Channel route which will provide the connection between the Black Sea and the Marmara Sea, due to the presence of Sakarya River and Sapanca Lake, it will be more economical in terms of excavation, time and cost during construction, it will pass a small number of settlements and may prevent the migration from east to west partially. The only difference for this issue is the high annuity created by the Istanbul Channel, which Mustafa COŞKUN put forward in an e-mail dated 06.09.2010. What is important is not the annuity Istanbul will gain, but rather prevent the migration to Istanbul, which has an ever-growing population and traffic problem, and create a reverse migration from Istanbul to the east.

\section{References}

[1] Andrussow, N., 1890, Expedition on "Seljanik" to Marmara Sea, Seleceted Works, IY.

[2] Meriç, E., 1995, İstanbul Boğazı öncesinde Marmara DeniziKaradeniz bağlantısının İzmit Körfezi-Sapanca Gölü-Sakarya Vadisi boyunca gerçekleştiğinin ön bulguları. İzmit Körfezi Kuvaternen İstifi, 295-301 (Ed. E. Meriç), İstanbul.

[3] Taner, G., 1995, İzmit Körfezi (Hersek Burnu-Kababurun) Kuvaterner istifinin pelesipod ve gastropod faunasi. İzmit Körfezi Kuvaternen İstifi, 219-239 (Ed. E. Meriç), İstanbul.

[4] Meriç, E., 1997a, Gelecek için geçmişe dönüş. Marmara Denizi Araştırmaları, Workshop-III, Bildiri Özetleri, 41-43, Ankara Üniv. Fen Fak. Jeoloji Müh. Böl., 2-3 Haziran 1997, Ankara.

[5] Meriç, E., 1997b, Gelecek için geçmișe dönüş. Popüler Bilim, 44, 21-23, Ankara.

[6] Meriç, E., Özdoğan, M., 1997, Back to the past for the future A-449, The Geological Society of America, Annual Meeting, 20-23 Ekim, 1997, Salt Lake C ity, Utah, ABD.

[7] Tschepalyga, A., 1995, Pliyo-Pleyistosen Karadeniz havzaları ve bunların Akdeniz ile ilişkileri. İzmit Körfezi Kuvaternen İstifi, 303-311 (Ed. E. Meriç), İstanbul.

[8] Büyükmeriç, Y., Wesselingh, F., Alçiçek, M. C., 2016, Middle late Pleistocene marine molluscs from İzmit Bay area eastern Marmara Sea Turkey and the nature of Marmara Black Sea corridors İzmit Bay eastern Marmara Sea. Quaternary International 401, 153-161.

[9] Dürüşken, Ç., Özbayoğlu, E., 1999, Genç Plinius’un Anadolu Mektupları - Plinius Epistulae, 10. Kitap, Yapı Kredi Yayınları, Altan Matbaacıllk Ltd. Şti.

[10] Uzunçarşıl1, İ. H., 1940, Sakarya Nehri'nin İzmit Körfezi'ne akıtılmasıyla Marmara ve Karadeniz'in birleşetirilmesi hakkınıda vesikalar ve tetkik raporları. Belleten 4 (14-15), 149-175, LXI-LXXI, Türk Tarih Kurumu Yayınları.

[11] Ağıralioğlu, N., 2016, İzmit Kanalı ve Yeni İstanbul. Ulaştırma\&Ulaşım (Dosya 2). İstanbul Teknik Üniversitesi Yayını, 72, 32-38, İstanbul. 